\title{
Propagule success of an invasive Poaceae depends on size of parental plants
}

\author{
Sucesso de propágulos de uma Poacea invasora depende do tamanho de plantas \\ parentais
}

Fabielle Mucio Bando ${ }^{1 *}$, Thaisa Sala Michelan ${ }^{1}$ and Sidinei Magela Thomaz ${ }^{1}$

\author{
${ }^{1}$ Núcleo de Pesquisas em Limnologia, Ictiologia e Aquicultura - NUPELIA, Programa de \\ Pós-graduação em Ecologia de Ambientes Aquáticos Continentais, Departamento de Biologia, \\ Universidade Estadual de Maringá - UEM, Av. Colombo, 5790, bloco H-90, CEP 87020-900, \\ Maringá, PR, Brazil \\ *e-mail: fabiellembando@gmail.com
}

Cite as: Bando, F.M., Michelan, T.S. and Thomaz, S.M. Propagule success of an invasive Poaceae depends on size of parental plants. Acta Limnologica Brasiliensia, 2016, vol. 28, e23.

Abstract: Aim: Viability and successful colonization of propagules by an invasive species may depend on several factors, such as parental plant size and propagules' fresh mass. Here, we tested (i) the effects of propagules' origin (from large and small parental plants); (ii) the position in the parental stem (apical, intermediate and basal) on the early development of the new sprouts of Urochloa arrecta; and (iii) if the regeneration success of $U$. arrecta was related with propagule fresh mass that comes from large or small parental plants. Methods: We selected 16 individuals of $U$. arrecta and separated them in two groups: (i) eight "large" (stem $\pm 1.5 \mathrm{~m}$ ) and (ii) eight "small" (stem $\pm 0.6 \mathrm{~m}$ ). For each individual, we cut three fragments with two nodes (considered as the "propagule") from the apical, intermediate and basal portions of the stem and we measured the fresh mass $(\mathrm{g})$, length $(\mathrm{cm})$ and distance between the two nodes $(\mathrm{cm})$ of all propagules of $U$. arrecta. In addition, after the experimentation, we measured the dry mass $(\mathrm{g})$ and length $(\mathrm{cm})$ of each new sprout of $U$. arrecta generated from each propagule. Results: We found that large parental individuals produced sprouts with longer length and greater dry mass. In contrast, the position in the parental stem did not significant influence the development of sprouts in $U$. arrecta. In addition, the propagule fresh mass played a role in the development of sprouts just for propagules from small parental plants. Conclusions: We found that the size of the parental individual is an important determinant of the development of new sprouts of this invasive species and the propagule fresh mass has a positive and significant influence in the success of $U$. arrecta only for propagules from smaller parental plants. We highlight that all propagules were viable, which could explain the reasons for this plant to be a successful invader.

Keywords: Urochloa arrecta; vegetative reproduction; invasiveness; non-native macrophytes.

Resumo: Objetivo: A viabilidade e o sucesso de colonização de propágulos por uma espécie invasora podem depender de vários fatores, tais como: o tamanho da planta parental e a massa fresca dos propágulos. Nesse contexto, testou-se (i) o efeito da origem de propágulos (plantas parentais grandes e pequenas); (ii) a posiçáo do fragmento da planta parental (apical, intermediário e basal) sobre o desenvolvimento inicial de novos brotos de Urochloa arrecta; e (iii) se o sucesso de regeneração de $U$. arrecta estava relacionado com a massa fresca dos propágulos oriundos de plantas parentais grandes e pequenas. Métodos: Conduziu-se um experimento, no qual 16 indivíduos de $U$. arrecta foram separados em dois grupos: (i) oito "grandes" (indivíduos com $\pm 1,5 \mathrm{~m}$ ) e oito "pequenos" (indivíduos com $\pm 0,6 \mathrm{~m}$ ). Para cada indivíduo, três fragmentos com dois nós foram cortados 
(considerados "propágulos") da porção apical, intermediário e basal e massa fresca (g), comprimento $(\mathrm{cm})$ e distância entre os dois nós $(\mathrm{cm})$ de todos os propágulos de $U$. arrecta foram mesurados. Além disso, após a experimentaçáo, foram realizadas medidas de massa seca $(\mathrm{g})$ e comprimento $(\mathrm{cm})$ dos brotos de $U$. arrecta gerados a partir dos propágulos. Resultados: Indivíduos parentais grandes produziram brotos com maior comprimento e massa (seca). Ao contrário, a posição da porção dos propágulos não influenciou significativamente o desenvolvimento de brotos. Porém, a massa fresca do propágulo de plantas parentais pequenas apresentou correlação positiva e significativa com a massa seca dos brotos gerados. Conclusóes: $\mathrm{O}$ tamanho do indivíduo parental é um importante determinante no desenvolvimento de novos brotos da espécie invasora $U$. arrecta. Além disso, a massa fresca dos propágulos possui uma influência positiva e significativa no sucesso de $U$. arrecta para propágulos provindos de plantas parentais pequenas. Ressalta-se que todos os propágulos foram viáveis, o que poderia explicar as razóes para esta planta ser uma invasora bem-sucedida.

Palavras-chave: Urochloa arrecta; reprodução vegetativa; potencial invasor; macrófitas náo nativas.

\section{Introduction}

Aquatic macrophytes have adaptations that allow efficient dispersion and rapid growth. Under appropriate conditions, several species become highly invasive (Santamaría, 2002) and can compromise the integrity of aquatic ecosystems (Pieterse \& Murphy, 1990; Fernandes et al., 2013). The high capacity to disperse and spread of invasive species is mainly due to their vegetative reproduction by rhizomes, stolons, tubers, turions and plant fragments (Barrat-Segretain \& Cellot, 2007; Riis et al., 2009). Macrophyte fragments can be generated by disturbances, such as herbivory and water flow (Riis \& Sand-Jensen, 2006). These fragments can disperse over large distances, transported by birds, water and boats, and they can colonize distant habitats (Madsen \& Smith, 1999; Santamaría, 2002).

Vegetative offsprings typically have much higher survivorship and growth rates than seedlings (Benson \& Hartnett, 2006; Ott \& Hartnett, 2011). The viability and successful colonization of fragments depend on several factors. For example, plant fragments coming from apical portions can develop faster than those coming from basal portions (Wu et al., 2007; Jiang et al., 2009), because the former portions are young and they have more meristematic activity (Riis et al., 2009). Also, fragments with high fresh mass have more reserves allowing to achieve greater regeneration and colonization success (Langeland \& Sutton, 1980; Jiang et al., 2009; Riis et al., 2009). Plants with different sizes (consequently different ages) can also generate propagules with different viability, because adult individuals allocate more energy to vegetative reproduction than young ones (Hartnett, 1990; Méndez \& Obeso, 1992; Sato, 2002).

Urochloa arrecta (Hack. ex T. Durand \& Schinz) Morrone \& Zuloaga is an aquatic Poaceae native to Africa with an emergent habit. This invasive species reaches high biomass in natural (e.g., lakes, river and streams) and artificial (reservoirs) environments (Michelan et al., 2010a; Pott et al., 2011; Fernandes et al., 2013; Amorim et al., 2015). U. arrecta is considered an aggressive species in aquatic environments because it regenerates quickly, even in sediments with low concentrations of nutrients and organic matter (Fasoli et al., 2015). It also has an efficient dispersal strategy and the fragments from stem apex are more resilient to desiccation (Michelan et al., 2010b). Despite the wide distribution of $U$. arrecta in Brazil and its negative effect on native flora (Michelan et al., 2010a; Fernandes et al., 2013) and on fish communities (Carniatto et al., 2013), few studies investigated its vegetative reproduction (e.g. Michelan et al., 2010b). For example, it is not known how or if the size (or age) of the parental plants affects the vegetative reproduction of $U$. arrecta propagules. This result could be important because the regeneration by propagules can regulate the dynamics of plant communities and influence the management of aquatic ecosystems (Bakker et al., 2013; Ogdahl \& Steinman, 2015; Xie et al., 2015). The propagule regeneration capacity is an important issue in population ecology and the understanding of the regeneration capacity of $U$. arrecta propagules could help to understand the formation of new stands of this species in initial or advanced stages of invasion in aquatic environments.

Here, we experimentally evaluated the success of vegetative reproduction of Urochloa arrecta. First, we tested the effects of the size of the parental plant (whether the propagule came from large or small plants) and positions from which the fragment originates (apical, intermediate and basal portions) on the new sprouts of $U$. arrecta. After that, we tested if the regeneration success of $U$. arrecta were 
correlated with propagule fresh mass. We tested three hypotheses: (i) propagules from large parental plants have higher regenerative capacity than small plants; (ii) propagules from apical portions have higher regenerative capacity than basal portions and (iii) the regenerative capacity of propagules is positively correlated with their fresh mass.

\section{Material and Methods}

The experiment was carried out in January 2014 in a greenhouse at the Universidade Estadual de Maringá in Brazil. We selected 16 individuals of $U$. arrecta that grew in the greenhouse and separated them in two groups: eight were categorized as "large" (stem $\pm 1.5 \mathrm{~m}$; see Figure $1 \mathrm{~A}$ ) and the others as "small" (stem $\pm 0.6 \mathrm{~m}$; see Figure 1B). We assumed that plants with large stems were older than plants with small stems. For each individual, we cut three fragments with two nodes (considered hereafter as the "propagule") from the apical, intermediate and basal portions of the stem (Figure 1C). We measured the fresh mass, length and distance between two nodes of all propagules of $U$. arrecta. The mean, the standard deviation (SD) and the minimum and maximum values of propagules fresh mass, length and distance between nodes from apical portions of $U$. arrecta were $0.8 \pm 0.31 \mathrm{~g}$ SD (minimum: $0.421 \mathrm{~g}$ and maximum: $1.218 \mathrm{~g}$ ), $14.56 \pm 0.91 \mathrm{~cm} \mathrm{SD}(12.3 \mathrm{~cm}$ and $15.7 \mathrm{~cm})$ and $9.11 \pm 1.22 \mathrm{~cm} \mathrm{SD}(7.3 \mathrm{~cm}$ and $11 \mathrm{~cm})$, respectively. For propagules from the intermediate portions, the mean values were $0.79 \pm 0.32 \mathrm{~g} \mathrm{SD}$ (minimum: $0.395 \mathrm{~g}$ and maximum: $1.197 \mathrm{~g}$ ) for fresh mass, $14.33 \pm 1.1 \mathrm{~cm} \mathrm{SD}(12 \mathrm{~cm}$ and $15.5 \mathrm{~cm})$ for length and $9.66 \pm 1.53 \mathrm{~cm} \mathrm{SD}(7 \mathrm{~cm}$ and $11.5 \mathrm{~cm})$ for distance between nodes. And for the basal portions, the mean propagules fresh mass was $0.58 \pm 0.22 \mathrm{~g}$ SD (minimum: 0.325 and maximum: $0.943 \mathrm{~g}$ ), the length was $13.39 \pm 0.87 \mathrm{~cm} \mathrm{SD}(12 \mathrm{~cm}$ and $15 \mathrm{~cm})$ and the distance between nodes was $8.02 \pm 1.19 \mathrm{~cm}$ SD $(6.5 \mathrm{~cm}$ and $10.9 \mathrm{~cm})$.

Propagules (apical, intermediate and basal originating from large and small parental' individuals) corresponding to each treatment were placed in trays $(15 \mathrm{~cm}$ wide by $15 \mathrm{~cm}$ deep by $6 \mathrm{~cm}$ high) with $3 \mathrm{~cm}$ of sediment. We used as sediment lateritic soil which was shown to be adequate for $U$. arrecta development in previous experiments (e.g., Michelan et al., 2010b). Each tray received one propagule and each treatment was replicated eight times totaling 48 trays. The trays were placed randomly in the greenhouse and maintained with tap water, which was replaced whenever necessary for maintain the water level $(2-4 \mathrm{~cm})$. After 37 days, the propagules rooted and formed new sprouts thus we considered them as being established (Figure 1D-G). We highlight that the propagules (composed of $U$. arrecta stems) do not grow, but they sprout new plants, what we used to gather our response variables. We removed each new sprout, washed them and measured their lengths $(\mathrm{cm})$ and dry mass (g DM; sprout + root; Figure 1H-I). We measured DM after drying the plant material in an oven at ca. $80^{\circ} \mathrm{C}$ until constant weight.
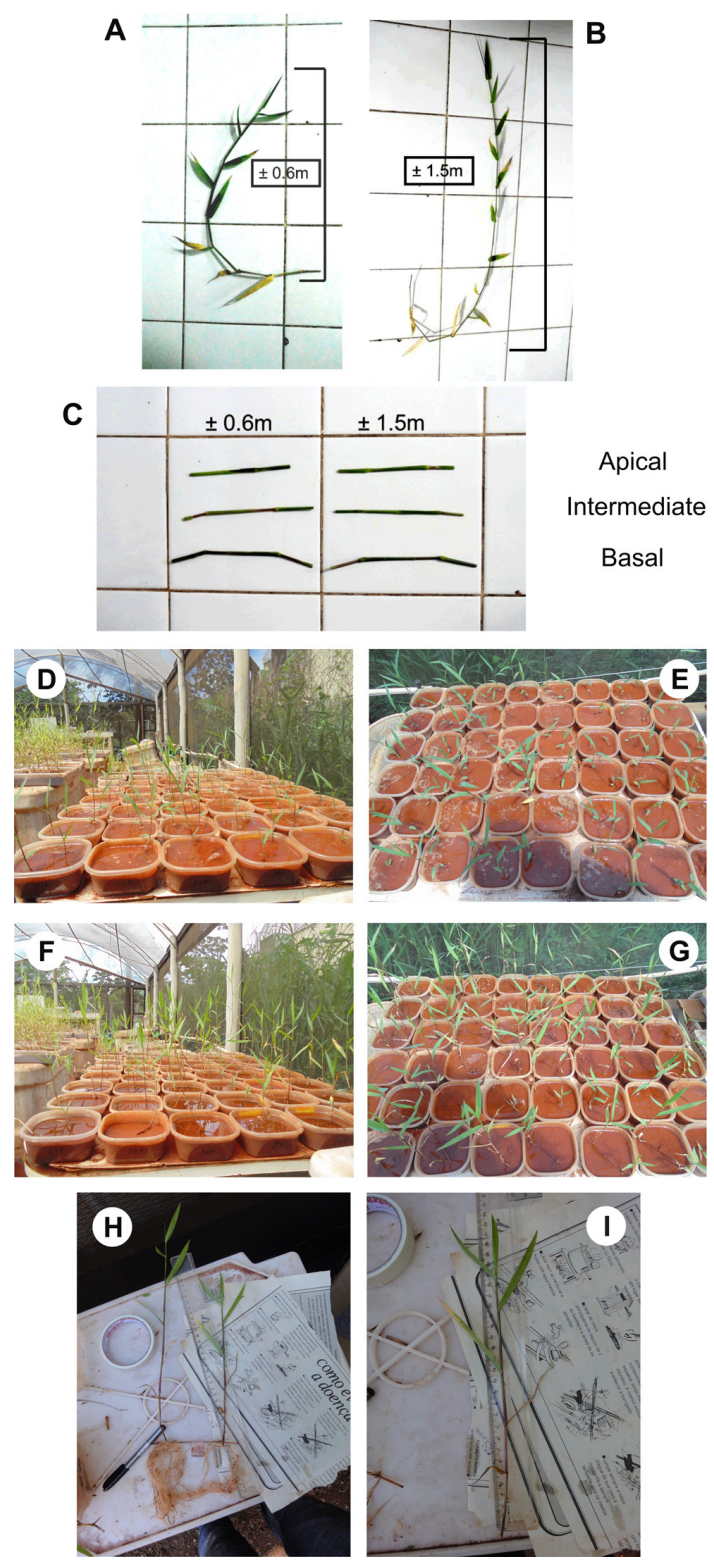

Figure 1. Pictures of parental size and propagules' positions of $U$. arrecta (A, B and C). Urochloa arrecta's sprouts after 10 days of the experiment beginning (D and $\mathbf{E}$ ) and at the end (37 days) of the experiment (F and $\mathbf{G})$. New sprouts of Urochloa arrecta generated (H) and measurement of the new sprout's length (I). 


\section{Data Analyses}

The effect of parental size (large or small) and position (apical, intermediate and basal) on the biological attributes of this exotic species (new sprout length and dry mass) was tested with a two-way Analysis of Variance (ANOVA). The normality and homoscedasticity of the data were tested using Shapiro-Wilk and Levene tests, respectively. We used as predictor variable the two categories: parental size (large or small) and the propagule position (apical, intermediate and basal), and as response variables the average value per tray of the invasive species' sprout length and sprout dry mass. We used the average values because the propagule of $U$. arrecta had two nodes and most of them produced two sprouts (one in each node).

In addition, we tested if the propagule regeneration success of $U$. arrecta was related to the propagule fresh mass from large (older) and small (younger) parental plants. For this purpose, we first used a Pearson correlation analysis to evaluate the bivariate relationships between the predictor variables (propagule's fresh mass, propagule's length and distance between the nodes). Considering that the three variables were significantly correlated (fresh mass $\mathrm{x}$ length: $r=0.51 ; P<0.001$; fresh mass $\mathrm{x}$ distance between the nodes: $r=0.77 ; P<0.001$; length $\mathrm{x}$ distance between the nodes: $r=0.64$; $P<0.001$ ), we decided to use only the propagule's fresh mass as predictor variable, because this variable better represents the amount of reserves required for a new generation. Then, to test if the propagule regeneration success of $U$. arrecta was related to the propagule fresh mass, we employed Pearson correlation between the propagule fresh mass and dry mass of new sprouts for large and small parental plants separately. We carried out these analyses separately for each group because the ANOVA two way indicated that the parental size of the plant had significant effect on new sprouts formation (see Results). In this analysis, the data were log transformed to meet the normality assumption.

Statistical analysis ANOVA two-way was performed using the program $\mathrm{R}$ environment (R Development Core Team, 2011) with 10.000 randomizations and the Pearson correlations were performed using the program STATISTICA 7.0 (StatSoft, 2007). We considered for all statistical analyses $P<0.05$ as significant.

\section{Results}

The sprouts generated by small parental plants propagules reached a mean length of $24.57 \pm 7.28 \mathrm{~cm}$ $\mathrm{SD}$ (from 13.65-40.9 cm; $\mathrm{N}=24$ ) and a mean dry mass of $0.46 \pm 0.16 \mathrm{~g}$ DM (from 0.15-0.8g; $\mathrm{N}=24$ ) after 37 days. The sprouts generated by large parental plants propagules reached a mean length of $34.9 \pm 8.93 \mathrm{~cm}$ SD (from $21.85-59.4 \mathrm{~cm} ; \mathrm{N}=24$ ) and a mean dry mass of $0.88 \pm 0.20 \mathrm{~g}$ DM (from 0.51-1.29 g; $\mathrm{N}=24$ ) after 37 days.

The two-way ANOVA showed a significant difference in the length and dry mass of sprouts generated by parental plants of different sizes (small and large; Table 1; Figure 2). The propagules of large parental plants produced lengthier sprouts (Figure 2A) with higher dry mass (Figure 2B) than the propagules of small parental plants.

However, the position of the propagules in the parental plant (apical, intermediate and basal) did not affect the length and dry mass of new sprouts of the exotic species (Table 1; Figure 2). The interaction between size and position was not significant (Table 1) from small (A) and large parental size (B).

The effects of propagule fresh mass on new sprouts dry mass differed between small and large parental propagules. The propagule fresh mass was significantly correlated with the dry mass of new sprouts for propagules of small parental plant size ( $\mathrm{r}=0.44, P=0.03$; Figure $3 \mathrm{~A}$ ). On the other hand, this relationship was not significant for propagules of large parental plant size $(r=0.03, P=0.89$; Figure 3B).

\section{Discussion}

Our results showed that the development of sprouts of the exotic species Urochloa arrecta depended on the size of the parental plant (larger plants produced lengthier and heavier sprouts),

Table 1. Two-way ANOVA results for effect of parental propagule size (large and small plants) and position (apical, intermediate and basal portions) on sprout length and dry mass $(\mathrm{N}=48)$.

\begin{tabular}{lccc}
\hline & DF & $\boldsymbol{F}$ & $\boldsymbol{P}$ \\
\hline Sprout length (cm) & & & \\
$\quad$ Size & $\mathbf{1}$ & $\mathbf{1 9 . 0 9}$ & $<\mathbf{0 . 0 0 1}$ \\
$\quad$ Position & 2 & 0.82 & 0.46 \\
$\quad$ Size and Position & 2 & 0.92 & 0.41 \\
$\quad$ Sprout dry mass (g DM) & & & \\
$\quad$ Size & $\mathbf{1}$ & $\mathbf{6 6 . 0 7}$ & $<\mathbf{0 . 0 0 1}$ \\
$\quad$ Position & 2 & 0.38 & 0.69 \\
$\quad$ Size and Position & 2 & 1.76 & 0.18 \\
\hline
\end{tabular}



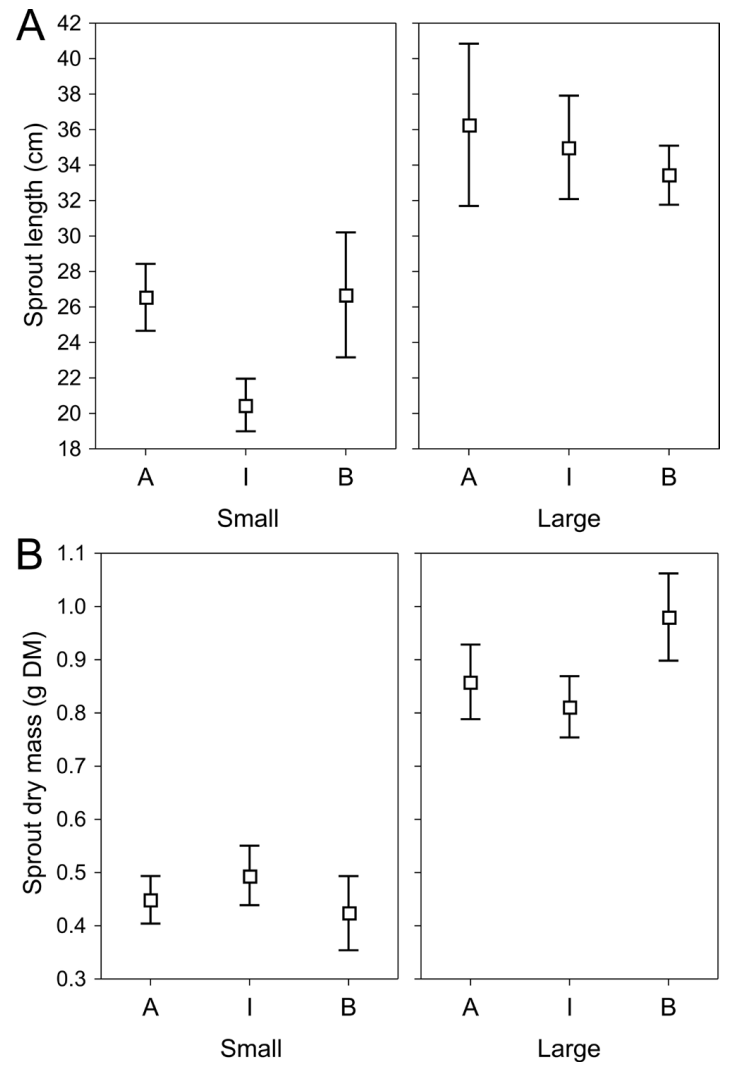

Figure 2. Mean ( \pm SE - Standard Error) of length (A) and dry mass (B) of $U$. arrecta's new sprouts at the end of experiment (37 days) in different parental size (large and small plants) and position from which the fragment originates (apical-A, intermediate-I and basal-B) $(\mathrm{N}=8$ for each treatment).

what corroborates our first hypothesis. However, sprout development did not depend on their origin in the parental plant (i.e., apical, intermediate or basal portions). Thus, our second hypothesis was rejected. In regard to our third hypothesis, we found mixing outcomes: propagule fresh mass affected positively new sprouts dry mass for propagules from small parental plants, but the relation was not significant for large parental plants.

Investigations conducted with other species of terrestrial and aquatic plants have shown that vegetative propagules (e.g., rhizomes, buds and tubers) with higher fresh mass regenerate more successfully than propagules with lower mass (Bowes et al., 1979; Weber, 2011; Deng et al., 2013). Smaller turions also have been shown to limit long-term survival of offspring (e.g. Van \& Steward, 1990). Therefore, our results that larger parental individuals (which generate propagules with higher fresh mass) produced more developed sprouts in terms of length and dry mass than smaller parental individuals (which generate propagules
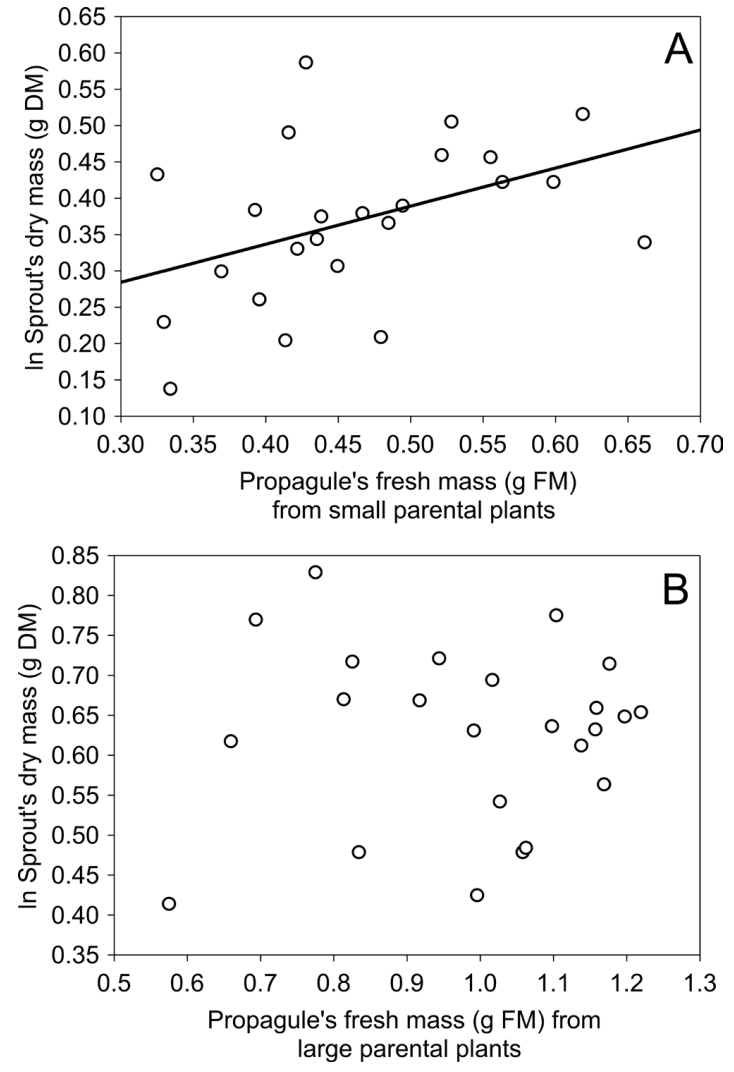

Figure 3. Relationship between $U$. arrecta' sprout dry mass (g DM) and propagule fresh mass (g FM) from small (A) and large parental size (B) $(\mathrm{N}=24$ each).

with lower fresh mass) reinforce the results obtained by the authors above.

The vegetative reproduction of $U$. arrecta in the field is probably more important than sexual reproduction, which is a common characteristic in Poaceae (Benson \& Hartnett, 2006; Ott \& Hartnett, 2011; Kellogg, 2015). Through new sprouts of vegetative reproduction, plants are able to respond rapidly to environmental conditions what leads to high resilience following herbivory, drought, fire or other disturbances. This high resilience can contribute to population persistence in variable environments (Ott \& Hartnett, 2011), what likely occurs with this invasive species. In addition, $U$. arrecta has long floating horizontal stems with nodes and internodes that allow it to spread and cover extensive water surface areas, as observed for other species of the same family (Deng et al., 2013). Each node and internode is able to produce roots, new stems and leaves (as we observed in our experiment; see Figure 1H-I), increasing the plant reproductive success.

The greater dry mass in the new $U$. arrecta sprouts originated from greater parental individuals. Other investigations showed that a higher concentration 
of starch and glucose usually occurs in older asexual reproductive structures, such as rhizomes (Klimeš et al., 1999) and maybe the same may occur in stems. It has also been shown that carbohydrate, starch and minerals stored in the nodes have a direct effect on the supply of nutrients to the vegetative reproduction (Chapin III et al., 1990; Klimeš et al., 1999) resulting in larger and more viable sprouts. We infer that the reserves that occur in stems and/or nodes of $U$. arrecta are important for successful asexual reproduction of this exotic invasive species. However, this inference deserves caution because it was based on experiments conducted with other plant species and we did not measure nutrient content and carbohydrates of plant tissues in our experiment. Measurements of the content of these compounds in future experiments may help to explain the success of $U$. arrecta propagules.

When we compared the relation between propagule fresh mass and sprout development for small and large parental plants separately, we found that propagule fresh mass correlated with sprout development only for small parental plants (see Figure 3). For large parental plants, it seems that sprouts regeneration does not depend of propagule fresh mass, as demonstrated by our correlation results. The difference of the effects of propagule fresh mass on success of $U$. arrecta by parental size probably occurs because of the variation of the fresh mass of propagules used in our experiment $(0.32 \mathrm{~g}$ to $0.66 \mathrm{~g}$ for small parental plants and $0.57 \mathrm{~g}$ to $1.21 \mathrm{~g}$ for large ones). In this sense, the regenerative capacity of propagules from large parental plants may possibly has reached a saturation point, above which the regeneration remains constant (see Figure 3).

Investigations testing the vegetative reproduction of plants have found that propagules originated in the apical portion of stems are the ones with the most successful development (Riis et al., 2009). Experiments carried with $U$. arrecta resulted in differences in the propagules' regeneration of apical, intermediate and basal parts, with the apical fragments having the biggest sprouts compared to the basal ones in response to desiccation (Michelan et al., 2010b). However, our results showed that propagule's viability did not depend on their position in the parental plant, i.e., regeneration did not differ among apical, intermediate or basal fragments when they were not stressed by desiccation. It has been shown that seasons influence regeneration features of macrophytes (Vári, 2013) and maybe the development of experiments in different periods of the year along with stress conditions, may explain differences between ours and other results (e.g. Michelan et al., $2010 \mathrm{~b}$ ). Although this is a speculation, our results suggest that asexual reproduction by propagules in $U$. arrecta occurs idiosyncratically, and this is a matter of concern because it suggests that any $U$. arrecta's propagule can regenerate in lotic and/or lentic environments when the water levels are relatively constant, as simulated in our experiment.

In short, we found that the size of the parental individual is an important determinant of the development of new sprouts of this invasive species. In addition, propagule fresh mass has a positive and significant influence in the success of $U$. arrecta only for propagules from smaller parental plants. Thus, in the future, experimental studies using $U$. arrecta' propagules and other species of Poaceae to test hypotheses about the success of invasion should take into consideration the parental plants size that generated the propagules and the propagule's fresh mass. These procedures are important for the interpretations of the data and for avoiding skewed results produced by experimental design errors.

Considering these results and due the quick development of $U$. arrecta in situations where even small propagules and with low fresh mass are able to generate new individuals (as observed in this study), it is possible to propose an alert to the management strategy for this exotic species when mechanical methods are used. Because these methods usually produce many fragments, they can facilitate the spread of this exotic species by propagules dispersal in different types of aquatic environments.

\section{Acknowledgements}

The authors thank Luis Mauricio Bini for the suggestions that improved our article. TSM and FMB thanks the Brazilian Council of Research (CNPq) and an organ of the Brazilian Government for the training of human resources (CAPES) for providing scholarships. SMT also thanks CNPq for continuous funding through a Research Productivity Grant.

\section{References}

AMORIM, S.R., UMETSU, C.A. and CAMARGO, A.F.M. Effects of a non-native species of Poaceae on aquatic macrophyte community composition: a comparison with a native species. Journal of Aquatic Plant Management, 2015, 53, 191-196.

BAKKER, E.S., SARNEEL, J., GULATI, R.D., LIU, Z. and VAN DONK, E. Restoring macrophyte 
diversity in shallow temperate lakes: biotic versus abiotic constraints. Hydrobiologia, 2013, 710(1), 2337. http://dx.doi.org/10.1007/s10750-012-1142-9.

BARRAT-SEGRETAIN, M.H. and CELLOT, B. Response of invasive macrophyte species to drawdown: The case of Elodea sp. Aquatic Botany, 2007, 87(4), 255-261. http://dx.doi.org/10.1016/j. aquabot.2007.06.009.

BENSON, E.J. and HARTNETT, D.C. The role of seed and vegetative reproduction in plant recruitment and demography in tallgrass prairie. Plant Ecology, 2006, 187(2), 163-178. http://dx.doi.org/10.1007/ s11258-005-0975-y.

BOWES, G.E., VAN, T.K., GARRARD, L.A. and HALLER, W.T. Adaptation to low light levels by Hydrilla. Journal of Aquatic Plant Management, 1979, 15, 32-35.

CARNIATTO, N., THOMAZ, S.M., CUNHA, E.R., FUGI, R. and OTA, R.R. Effects of an invasive alien Poaceae on aquatic macrophytes and fish communities in a Neotropical Reservoir. Biotropica, 2013, 45(6), 747-754. http://dx.doi.org/10.1111/ btp. 12062 .

CHAPIN III, F.S., SCHULZE, E.-D. and MOONEY, H.A. The ecology and economics of storage in plants. Annual Review of Ecology and Systematics, 1990, 21(1), 423-447. http://dx.doi.org/10.1146/annurev. es.21.110190.002231.

DENG, Z., CHEN, X., XIE, Y., LI, X., PAN, Y. and LI, F. Effects of size and vertical distribution of buds on sprouting and plant growth of the clonal emergent macrophyte Miscanthus sacchariflorus (Poaceae). Aquatic Botany, 2013, 104, 121-126. http://dx.doi. org/10.1016/j.aquabot.2012.08.004.

FASOLI, J.V.B., MICHELAN, T.S. and THOMAZ, S.M. Sediment composition mediates the invasibility of aquatic ecosystems by a non-native Poaceae species. Acta Limnologica Brasiliensia, 2015, 27(2), 165-170. http://dx.doi.org/10.1590/S2179-975X5214.

FERNANDES, L.F.G., TEIXEIRA, M.C. and THOMAZ, S.M. Diversity and biomass of native macrophytes are negatively related to dominance of an invasive Poaceae in Brazilian sub-tropical streams. Acta Limnologica Brasiliensia, 2013, 25(2), 202-209. http://dx.doi.org/10.1590/S2179$975 \mathrm{X} 2013000200011$.

HARTNETT, D.C. Size-dependent allocation to sexual and vegetative reproduction in four clonal composites. Oecologia, 1990, 84(2), 254-259. http:// dx.doi.org/10.1007/BF00318281.

JIANG, J., AN, S., ZHOU, C., GUAN, B., SUN, Z., CAI, Y. and LIU, F. Fragment propagation and colonization ability enhanced and varied at node level after escaping from apical dominance in submerged macrophytes. Journal of Integrative Plant Biology,
2009, 51(3), 308-315. PMid:19261074. http:// dx.doi.org/10.1111/j.1744-7909.2008.00732.x.

KELLOGG, E.A. Flowering Plants. Monocots: Poaceae. Switzerland: Springer International Publishing, 2015.

KLIMEŠ, L., KLIMEŠOVÁ, J. and CÍZKOVÁ, H. Carbohydrate storage in rhizomes of Phragmites australis: the effects of altitude and rhizome age. Aquatic Botany, 1999, 64(2), 105-110. http://dx.doi. org/10.1016/S0304-3770(99)00016-9.

LANGELAND, K.A. and SUTTON, D.L. Regrowth of hydrilla from axillary buds. Journal of Aquatic Plant Management, 1980, 18, 27-29.

MADSEN, J.D. and SMITH, D.H. Vegetative spread of dioecious Hydrilla colonies in experimental pounds. Journal of Aquatic Plant Management, 1999, 37, 25-29.

MÉNDEZ, M. and OBESO, J.R. Size-dependent reproductive and vegetative allocation in Arum italicum (Araceae). Canadian Journal of Botany, 1992, 71(2), 309-314. http://dx.doi.org/10.1139/b93-032.

MICHELAN, T.S., THOMAZ, S.M., CARVALHO, P., RODRIGUES, R.B. and SILVEIRA, M.J. Regeneration and colonization of an invasive macrophyte grass in response to desiccation. Natureza \& Conservação, 2010b, 8(2), 133-139. http://dx.doi. org/10.4322/natcon.00802005.

MICHELAN, T.S., THOMAZ, S.M., MORMUL, R.P. and CARVALHO, P. Effects of an exotic invasive macrophyte (tropical signalgrass) on native plant community composition, species richness and functional diversity. Freshwater Biology, 2010a, 55(6), 1315-1326. http://dx.doi.org/10.1111/j.13652427.2009.02355.x.

OGDAHL, M.E. and STEINMAN, A.D. Factors influencing macrophyte growth and recovery following shoreline restoration activity. Aquatic Botany, 2015, 120, 363-370. http://dx.doi. org/10.1016/j.aquabot.2014.10.006.

OTT, J.P. and HARTNETT, D.C. Bud production and dynamics of flowering and vegetative tillers in Andropogon gerardii (Poaceae): The role of developmental constraints. American Journal of Botany, 2011, 98(8), 1293-1298. PMid:21788531. http://dx.doi.org/10.3732/ajb.1000264.

PIETERSE, A.H. and MURPHY, K.J. Aquatic weeds: the ecology and management of nuisance aquatic vegetation. Oxford: Oxford Science Publications, 1990.

POTT, V.J., POTT, A., LIMA, L.C.P., MOREIRA, S.N. and OLIVEIRA, A.K.M. Aquatic macrophyte diversity of the Pantanal wetland and upper basin. Brazilian Journal of Biology = Revista Brasileira de Biologia, 2011, 71(1, Suppl 1), 255-263. PMid:21537598.

R DEVELOPMENT CORE TEAM. $R$ : A language and environment for statistical computing [online]. Vienna: R Foundation for Statistical Computing, 
2011 [viewed 02 Dec. 2015]. Available from: <http:// www.R-project.org/

RIIS, T. and SAND-JENSEN, K. Dispersal of plant fragments in small streams. Freshwater Biology, 2006, 51(2), 274-286. http://dx.doi.org/10.1111/j.13652427.2005.01496.x.

RIIS, T., MADSEN, T.V. and SENNELS, R.S.H. Regeneration, colonisation and growth rates of allofragments in four common stream plants. Aquatic Botany, 2009, 90(2), 209-212. http://dx.doi. org/10.1016/j.aquabot.2008.08.005.

SANTAMARÍA, L. Why are most aquatic plants widely distributed? Dispersal, clonal growth and smallscale heterogeneity in a stressful environment. Acta Oecologica, 2002, 23(3), 137-154. http://dx.doi. org/10.1016/S1146-609X(02)01146-3.

SATO, T. Size-dependent resource allocation among vegetative propagules and male and female functions in the forest herb Laportea bulbifera. Oikos, 2002, 96(3), 453-462. http://dx.doi.org/10.1034/j.16000706.2002.960307.x.

STATSOFT. Statistical: data analysis software system. Version 8.0 [online]. 2007 [viewed 02 Dec. 2015]. Available from: www.statsoft.com

VAN, T.K. and STEWARD, K.K. Longevity of monoecious hydrilla propagules. Journal of Aquatic Plant Management, 1990, 28, 74-76.
VÁRI, A. Colonization by fragments in six common aquatic macrophyte species. Fundamental Applied Limnology, 2013, 183(1), 15-26. http://dx.doi. org/10.1127/1863-9135/2013/0328.

WEBER, E. Strong regeneration ability from rhizome fragments in two invasive clonal plants (Solidago canadensis and S. gigantea). Biological Invasions, 2011, 13(12), 2947-2955. http://dx.doi.org/10.1007/ s10530-011-9977-y.

WU, Z., ZUO, J., MA, J., WU, J., CHENG, S. and LIANG, W. Establishing submerged macrophytes via sinking and colonization of shoot fragments clipped off manually. Wuhan University Journal Natural Sciences, 2007, 12(3), 553-557. http://dx.doi. org/10.1007/s11859-006-0057-6.

XIE, D., ZHOU, H., ZHU, H., JI, H., LI, N. and AN, S. Differences in the regeneration traits of Potamogeton crispus turions from macrophyte- and phytoplankton-dominated lakes. Nature: Scientific Reports, 2015, 5, 12907. http://dx.doi.org/10.1038/ srep12907.

Received: 08 April 2016 Accepted: 21 October 2016 